\title{
Growth and carcass traits of Boer $x$ Alpine goats slaughtered at the ages of 31 and 50 weeks *
}

\author{
J. Luo, T. Sahlu' and A.L. Goetsch \\ E (Kika) de la Garza Institute for Goat Research, Langston University \\ P.O. Box 730, Langston. Oklahoma 73050 USA
}

(Received 20 September 1999; accepted 8 May 2000)

\section{ABSTRACT}

Age and weight of meat goats vary considerably, and little knowledge exists concerning differences in growth, efficiency of feed use, and carcass characteristics of goats slaughtered at different times. Fourteen Boer $x$ Alpine kids ( $14 \pm 0.6 \mathrm{~kg}$ initial body weight) were used to determine effects of feeding from 15 to $31 \mathrm{wk}$ (Phase 1) and from 38 to $50 \mathrm{wk}$ (Phase 2) on feed intake, body weight (BW) gain, fecd efficiency, plasma constituents, internal organ mass, and carcass traits. All wether kids consumed ad libitum diets with 20 and $16 \%$ crude protein and 33 and $40 \%$ neutral detergent fibre diet in Phase 1 and 2, respectively. Body weight after Phase 1 and 2 was $42 \pm 2.0$ and $57 \pm 0.8 \mathrm{~kg}$, respectively: BW gain was greater $(\mathrm{P}<0.01)$ in Phase 1 than in Phase 2 (228 vs $118 \mathrm{~g} /$ day); and the ratio of $\mathrm{BW}$ gain to dry matter intake differed $(\mathrm{P}<0.01)$ between phases $(0.19$ in Phase 1 vs 0.10 in Phase 2). Cold carcass weight ( 20.4 vs $29.6 \mathrm{~kg} ; \mathrm{P}<0.01$ ), dressing percentage (50.1 vs $56.5 \% ; \mathrm{P}<0.01$ ), and percentage of carcass fat ( 16.4 vs $20.2 \% ; \mathrm{P}=0.09$ ) were lower after Phase 2 than Phase 1 , and leg cut percentage ( 30.5 vs $28.3 \% ; P=0.07$ ), carcass bone percentage ( 23.7 vs $20.6 \% ; \mathrm{P}=0.01$ ), and backfat thickness $(0.44$ vs $0.30 \mathrm{~cm}: \mathrm{P}=0.04)$ were greater after Phase 1 . However, carcass ican percentage (58.3 and 57.1\%) and the percentage of noncarcass fat (6.39 and 7.07\% for Phase 1 and 2 , respectively) were similar between phases $(\mathrm{P}>0.10)$. In conclusion, change with age of growing crossbred meat goats in levels of carcass and noncarcass fat may be dissimilar, and backfat thickness may not be a reliable indicator of differences among ages in whole body, carcass, or noncarcass fat. Average daily gain and efficiency of feed utilisation were substantially lower when Boer $x$ Alpine wether kids were reared to $50 \mathrm{vs} 31 \mathrm{wk}$ of age, which must be compared with magnitudes of change in carcass traits and the importance of such characteristics to product value when determining optimal slaughter age and time.

KEY WORDS: goats, performance, age, carcass

\footnotetext{
* Supported by USDA-CSREES 95-38814-1732

' Corresponding author
} 


\section{INTRODUCTION}

The Alpine goat has high milk production but low rates of carcass fat and protein deposition compared with traditional meat goat breeds (Glimp, 1995). Thus, crossbreeding Alpines with a meat goat breed is a means of increasing profit potential from sale of kids for meat production. Boer goats are more muscular and larger in mature size than other breeds of goats (Van Niekerk and Casey, 1988); Boer crossbred kids have been $15-20 \%$ heavier at weaning than kids of common goat breeds (Garza and Garza, 1997). Thus, using the Boer goat for production of crossbred kids has had a profound impact on the meat goat industry (Blackburn, 1995). Likewise, crossing the Alpine goat with the Boer could produce a genotype with high growth rate and carcass characteristics suitable for goat meat market specifications.

Changes in body weight gain, feed efficiency, and carcass characteristics with advancing age are well understood for cattle and sheep. Briefly, efficiency of feed utilisation and body weight gain decrease with advancing time as adipose tissue accretion increases and lcan tissue deposition declines, although degrees of change vary with factors such as particular stages of maturity, dict composition, and previous nutritional plane. Concomitantly, whole body fat content increases with agc, again with magnitudes of change for different depots or sites depending on aforementioned conditions (Owens et al., 1995). For cattle and sheep, current consumer demands dictate a minimal stage of maturity required to achieve acceptable intramuscular fat or marbling, necessitating the incurrence of relatively inefficient feed utilisation in the latter phase of production compared with earlier performance. However, market demands for goats are different, in that presently high carcass fat levels are not desired by U.S. consumers, many of which are of ethnic minorities. Thus, there is need to evaluate differences in efficiency of production and carcass characteristics between meat goats of different ages, in order to determine optimal ages and times for slaughter.

Primary objectives of this study were to compared average daily gain, feed efficiency, and carcass characteristics of castrate Bocr $x$ Alpine kids in two growing periods or at two ages under intensive management conditions.

\section{MATERIAL AND METHODS}

\section{Animals and treatments}

Sixteen male kids from Boer-sired Alpine does, born in July, 1997 were separated from does, weighed, car-tagged within a few hours of birth, and transferred to $91 \times 76 \times 91 \mathrm{~cm}$ stainless steel cages. Colostrum was offered the first day; thereaf- 
ter, all kids were offered goat milk ad libitum twice daily and had free access to water and a maizc-based, $14 \%$ crude protein diet (DM basis). At 45 days of agc, all kids were moved to a grass-based pasture and received supplemental concentrate and decreasing amounts of goat milk until weaning at 60 days of age. Kids were castrated immediately after weaning.

\section{Phase I}

At an average body weight (BW) of $12 \pm 0.7 \mathrm{~kg}$ and age of approximately $12 \mathrm{wk}$, kids were randomly allotted in pairs to eight elevated $1.2 \times 0.9 \mathrm{~m}$ pens. Following a 2 -wk adaptation period, all kids received a pelleted diet containing (according to the manufacturer), \%: crude protein 20; fat 2.5 , and crude fibre 12 , and based on maize, soyabean meal, oats and lucerne meal. Kids were fed once daily at $8.30 \mathrm{~h}$, and refusals were removed and weighed before feeding. BW was determined before feeding at 2-wk intervals. Two goats were removed from Phase 1 because of an injury and an unexplained death. At the end of Phase 1, the seven kids from four pens were slaughtered, with an average age of $31 \mathrm{wk}$.

\section{Phase 2}

Phase 2 was initiated in March, 1998 with the seven animals not slaughtered at the end of Phase 1. At the beginning of Phase 2, kids were treated for internal parasites, vaccinated, wcighed, and placed in individual elevated $1.0 \times 0.6 \mathrm{~m}$ pens. After being switched to Phase 2 diet, kids underwent a 7 -wk period with the same management as in Phase 1 and, thus, began Phase 2 at an average age of $38 \mathrm{wk}$. Errors in feed intake monitoring immediately after Phase 1 necessitated the long adjustment period. Kids had free access to a $16 \%$ crude protein (DM basis; according to the manufacturer) pelleted diet based on maize, soyabean meal, and lucerne meal, which was given once daily at $10.00 \mathrm{~h}$. This diet was quite similar to that in Phase 1, with a lower crude protein concentration because of expected decreasing protein deposition with increasing BW. One animal died in the middle of Phase 2 because of urinary calculi. Kids were slaughtered at an age of $50 \mathrm{wk}$.

\section{Feed analysis}

Feed samples were collected weekly and composited over 4-wk periods or the 5 -wk period at the end of Phase 1. Samples were placed in a $60^{\circ} \mathrm{C}$ oven for $48 \mathrm{~h}$, ground through a Wilcy mill (1-mm screen), and analyzed for dry matter, ash, crude protein (AOAC,1990), acid detergent fibre and neutral detergent fibre (Goering and Van Soest, 1970). 
Plasma metabolite analysis

Blood samples in Phases 1 and 2 were collected at 4-wk intervals via venipuncture, preprandial, into two $7-\mathrm{mL}$ tubes containing potassium oxalate and sodium fluoride for analysis of nonestrified fatty acids (NEFA) or sodium heparin for measurement of glucose, urea and amino acid level. Tubes were immediately chilled in an ice bath, transported to the laboratory, and centrifuged at $1500 \times \mathrm{g}$ at $4^{\circ} \mathrm{C}$ for $15 \mathrm{~min}$. Two plasma aliquots were stored at $-20^{\circ} \mathrm{C}$ pending analysis.

The concentration of NEFA in plasma was determined using NEFA-C kit (Cat. No. 990-75401; Wako Pure Chemical Industries, Ltd., Osaka, Japan). The concentration of plasma urea nitrogen $(\mathrm{N})$ was determined by the method of Chaney and Marbach (1962), and plasma glucose was assayed colorimetrically using a Technicon Autoanalyzer II (Technicon Instrument Co., Tarrytown, NY). Plasma free amino acid analysis was performed by high presure liquid chromatography with an AminoQuant (Hewlett Packard, San Fernando, CA) chromatograph, using the method of Puchala et al. (1998).

\section{Slaughter}

Each kid was weighed prior to slaughter. At slaughter, blood was weighed, the oesophagus was ligated, and the carcass underwent processing according to normal commercial practices (Aziz et al., 1993). Head, feet, and hide weights were recorded; after the rectum was ligated, the entire alimentary tract and kidneys were removed and the trachea, lungs, liver, kidneys, heart, spleen, and thymus, with associated fat, were weighed as one entity. Individual weights for the heart, liver, kidneys, and lungs, without fat, were determined. Digesta-free weights of the small intestine, large intestine plus caecum, and stomach were obtained after removal of digesta. Weights of kidncy, pclvic, and heart fat (KPH) and of other noncarcass fat (associated with the digestive tract) were recorded as well.

Hot carcass weight, without kidncys, was recorded and carcasses were reweighed after storage at $4^{\circ} \mathrm{C}$ for $24 \mathrm{~h}$ to obtain cold carcass weight. Cold carcasses were graded according to USDA (1982) Standards at the Oklahoma State University abattoir. Scores were given for overall carcass quality grade, carcass conformation, degree of flank fat streaking, skcletal maturity, and lean maturity. Carcasses were then halved through the vertebral midline using a band saw, and each half was then weighed. Backfat thickness was measured on the left side of the carcass between the 12th and 13th ribs at the midpoint of the lateral length of the longissimus dorsi muscle (Boggs and Merkel, 1990). The left half of each carcass was separated into retail cuts, and weights of dissected muscle, bone, and fat components for each retail cut were determined. Thus, carcass fat includes subcutaneous and intermuscular depots, and the lean tissue encompasses intramuscular fat. 


\section{Statistical analyses}

Statistical analyses for all data were performed by General Linear Models procedures of SAS (1990). Because kids were fed in groups in Phase 1, all data were analysed using pen as the experimental unit; animal was the experimental unit in Phase 2. For performance and slaughter measures during entire phases, the model consisted of phase. In addition, to investigate changes with advancing age or time within phases, some data were analysed by phase. In this regard, blood parameters were analysed as a completely randomized design with a model including 4-wk period, or for Phase 1 also the final period $5 \mathrm{wk}$ in length. Orthogonal contrasts were performed to test linear, quadratic, and cubic effects of period within phase. A P-value less than 0.10 was considered significant.

\section{RESULTS}

\section{Diet composition}

The chemical composition of the diets averaged: crude protein 21.1 and $17.7 \%$, ash 9.6 and $6.0 \%$, neutral detergent fibre 32.9 and $39.6 \%$, and acid detergent fibre 18.5 and $17.8 \%$ in Phase 1 and 2, respectively.

\section{Growing performance}

Body weight increased linearly ( $\mathrm{P}<0.01$ ) with advancing age in both phases (Figure 1). Nonetheless, BW gain changed quadratically $(\mathrm{P}=0.04)$ during Phase 1, being greatest in the first $4 \mathrm{wk}$ (Figure 2). Conversely, BW gain increased linearly $(\mathrm{P}<0.001)$ with advancing time in Phase 2 . Overall $\mathrm{BW}$ gain during Phase I was more than $100 \mathrm{~g} /$ day greater $(\mathrm{P}<0.001)$ than in Phase 2 (i.e., 228 vs $118 \mathrm{~g} /$ day; Table 1).

Dry matter intake increased linearly with advancing time $(\mathrm{P}<0.01)$ in both Phases (Figure 2). Overall dry matter intake was similar $(\mathrm{P}>0.10)$ between phases. The FCR in Phase 1 was $0.26,0.17,0.17$, and 0.15 during wk 15-18, 19-22, 23-26, and $27-31$, respectively $(\mathrm{SE}=0.010$ ) (linear, quadratic, and cubic effects; $\mathrm{P}<0.01$ ), and in Phasc 2 was $0.10,0.09$, and 0.10 during wk 39-42, 43-46, and 47-50, respectively $(\mathrm{SE}=0.013)(\mathrm{P}<0.01)$.

\section{Carcass traits}

Differences between Phases for many measures were as expected (Table 1). For example, Phase 2 means greater than those for Phase 1 were noted for cold 

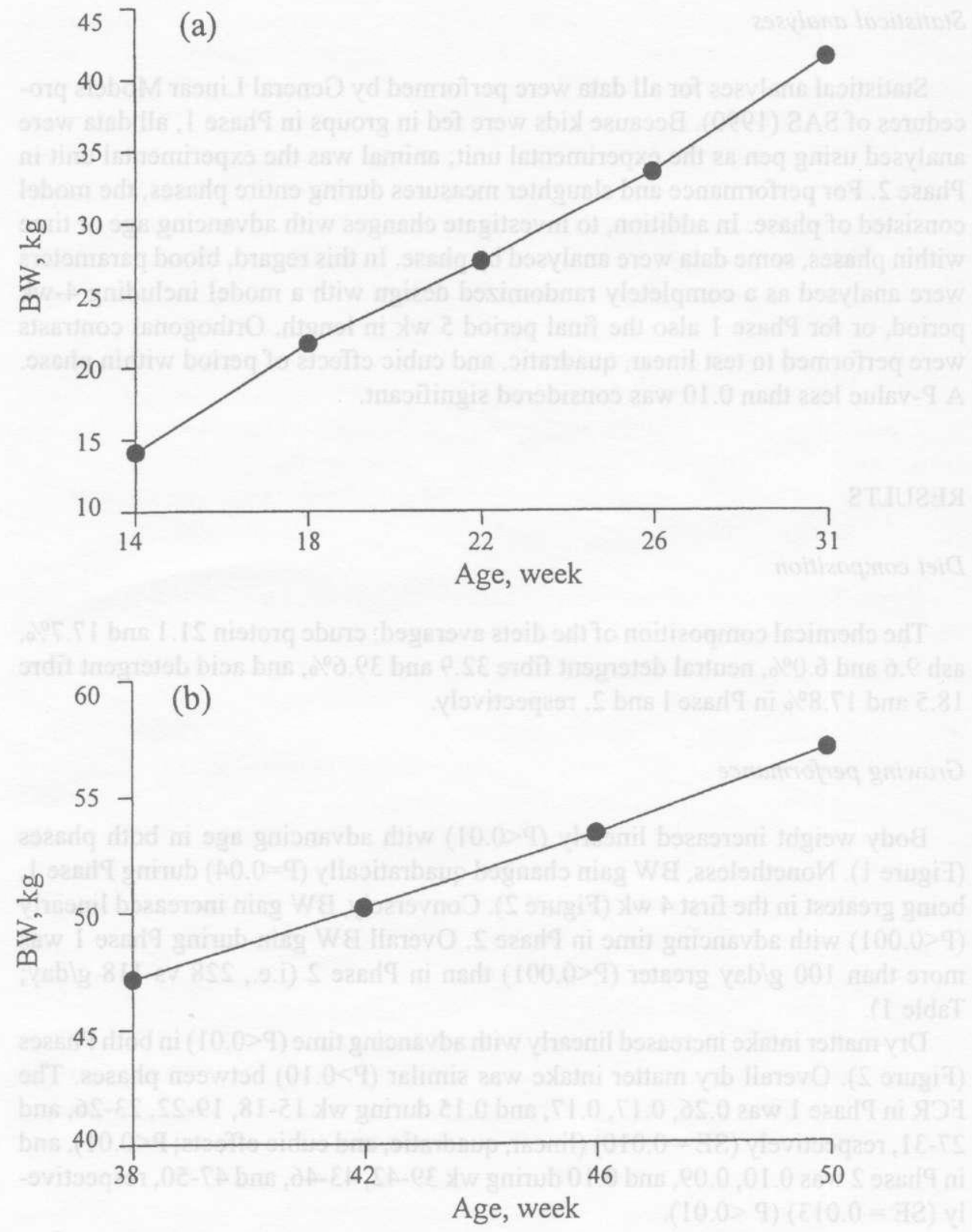

Figure 1. Body weight (BW) of Boer $x$ Alpine goats in Phase 1 (a) $(\mathrm{SE}=1.45 \mathrm{~kg})$ and 2 (b) $(\mathrm{SE}=$ $0.351 \mathrm{~kg})$ 

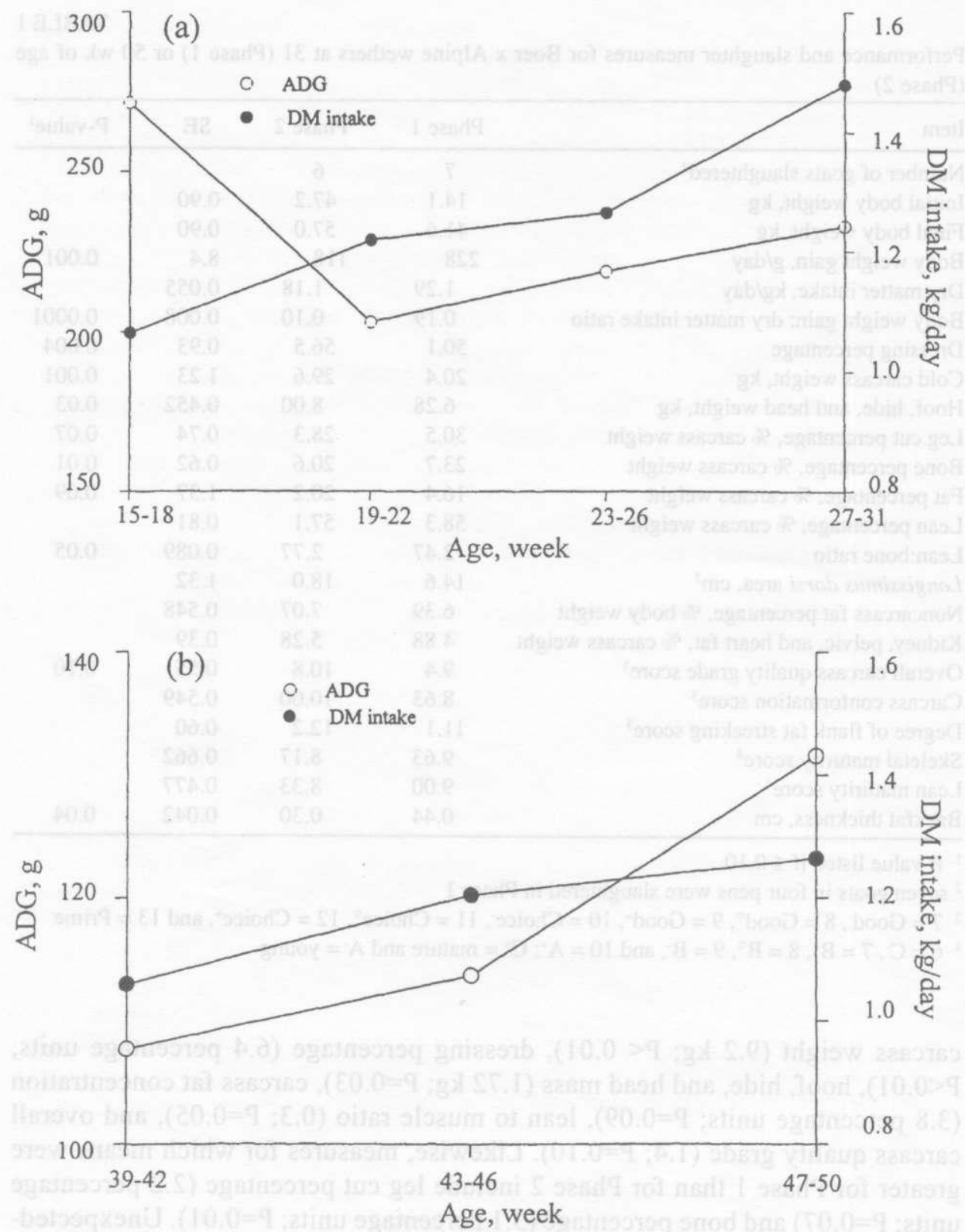

Figure 2. Average daily gain (ADG) and dry matter (DM) intake for Boer x Alpine goat in Phase 1 (a) (pooled SE $18.8 \mathrm{~g}$ and $0.113 \mathrm{~kg}$, respectively) and 2 (b) (pooled SE $19.3 \mathrm{~g}$ and $0.048 \mathrm{~kg}$, respectively). Phase 1 ADG: quadratic effect of time ( $\mathrm{P}=0.04)$; Phase 2 ADG: linear effect of time $(\mathrm{P}<0.01)$; Phase 1 DM intake: linear, quadratic, and cubic effects of time $(\mathrm{P}<0.01)$ 
TABLE 1

Performance and slaughter measures for Boer x Alpine wethers at 31 (Phase 1) or 50 wk of age (Phase 2)

\begin{tabular}{|c|c|c|c|c|}
\hline Item & Phase ! & Phase 2 & SE & P-value ${ }^{1}$ \\
\hline Number of goats slaughtered ${ }^{2}$ & 7 & 6 & & \\
\hline Initial body weight, $\mathrm{kg}$ & 14.1 & 47.2 & 0.90 & \\
\hline Final body weight, $\mathrm{kg}$ & 41.6 & 57.0 & 0.90 & \\
\hline Body weight gain, g/day & 228 & 118 & 8.4 & 0.001 \\
\hline Dry matter intake, $\mathrm{kg} /$ day & 1.29 & 1.18 & 0.055 & \\
\hline Body weight gain: dry matter intake ratio & 0.19 & 0.10 & 0.008 & 0.0001 \\
\hline Dressing percentage & 50.1 & 56.5 & 0.93 & 0.004 \\
\hline Cold carcass weight, $\mathrm{kg}$ & 20.4 & 29.6 & 1.23 & 0.001 \\
\hline Hoof, hide, and head weight, $\mathrm{kg}$ & 6.28 & 8.00 & 0.452 & 0.03 \\
\hline Leg cut percentage, $\%$ carcass weight & 30.5 & 28.3 & 0.74 & 0.07 \\
\hline Bone percentage, $\%$ carcass weight & 23.7 & 20.6 & 0.62 & 0.01 \\
\hline Fat percentage, $\%$ carcass weight & 16.4 & 20.2 & 1.37 & 0.09 \\
\hline Lean percentage, $\%$ carcass weight & 58.3 & 57.1 & 0.81 & \\
\hline Lean:bone ratio & 2.47 & 2.77 & 0.089 & 0.05 \\
\hline Longissimus dorsi area, $\mathrm{cm}^{2}$ & 14.6 & 18.0 & 1.32 & \\
\hline Noncarcass fat percentage, $\%$ body weight & 6.39 & 7.07 & 0.548 & \\
\hline Kidney, pelvic, and heart fat, \% carcass weight & 4.88 & 5.28 & 0.39 & \\
\hline Overall carcass quality grade score 3 & 9.4 & 10.8 & 0.55 & 0.10 \\
\hline Carcass conformation score ${ }^{3}$ & 8.63 & 10.00 & 0.549 & \\
\hline Degree of tlank fat streaking score ${ }^{3}$ & 11.1 & 12.2 & 0.60 & \\
\hline Skeletal maturity scorc ${ }^{4}$ & 9.63 & 8.17 & 0.662 & \\
\hline Lean maturity score ${ }^{4}$ & 9.00 & 8.33 & 0.477 & \\
\hline Backfat thickness, cm & 0.44 & 0.30 & 0.042 & 0.04 \\
\hline
\end{tabular}

1 P-value listed if $\leq 0.10$

2 seven goats in four pens were slaughtered in Phase 1

$37=$ Good $^{\prime}, 8=$ Good $^{\circ}, 9=$ Good $^{+}, 10=$ Choice $^{*}, 11=$ Choice $^{\circ}, 12=$ Choice $^{+}$, and $13=$ Prime

${ }^{+} 6=\mathrm{C}, 7=\mathrm{B}^{+}, 8=\mathrm{B}^{\circ}, 9=\mathrm{B}^{-}$, and $10=\mathrm{A}^{+} ; \mathrm{C}^{+}=$mature and $\mathrm{A}^{-}=$young

carcass weight $(9.2 \mathrm{~kg} ; \mathrm{P}<0.01)$, dressing percentage $(6.4$ percentage units; $\mathrm{P}<0.01)$, hoof, hide, and head mass $(1.72 \mathrm{~kg} ; \mathrm{P}=0.03)$, carcass fat concentration (3.8 percentage units; $\mathrm{P}=0.09$ ), lean to muscle ratio $(0.3 ; \mathrm{P}=0.05)$, and overall carcass quality grade $(1.4 ; \mathrm{P}=0.10)$. Likewise, measures for which means werc greater for Phase 1 than for Phase 2 include leg cut percentage (2.2 percentage units; $\mathrm{P}=0.07$ ) and bone percentage ( 3.1 percentage units; $\mathrm{P}=0.01$ ). Unexpectedly, backfat thickness was $0.14 \mathrm{~cm}$ greater $(\mathrm{P}=0.04)$ for Phase 1 vs Phase 2 , and the percentage of lean in the carcass, longissimus dorsi arca, noncarcass fat, KPH fat, carcass conformation score, degrec of flank fat streaking score, skeletal maturity score, and lean maturity score were similar $(\mathrm{P}>0.10)$ between phases. 


\section{Internal organs}

There were no differences $(\mathrm{P}>0.10)$ between phases in weights of the heart, kidneys, liver, lungs, and blood (Table 2). Mass of the stomach ( $\mathrm{P}=0.02)$, including the rumen, reticulum, omasum, and abomasum, and of the large intestine plus caccum $(\mathrm{P}=0.08)$ were considerably greater after Phase 2 than Phase 1 , whereas small intestine mass was less $(\mathrm{P}=0.01)$ after Phase 2 . Factors responsible for the difference between phases in small intestine mass are unclear.

TABLE 2

Internal organ mass for Boer $x$ Alpine wethers at 31 (Phase 1) or 50 wk of age (Phase 2) ${ }^{1}$

\begin{tabular}{|c|c|c|c|c|}
\hline \multirow{2}{*}{ Item } & Phase 1 & Phase 2 & \multirow{2}{*}{ SE } & \multirow{2}{*}{ P-value } \\
\hline & \multicolumn{2}{|c|}{$\mathrm{kg}$} & & \\
\hline Heart & 0.185 & 0.207 & 0.0138 & \\
\hline Kidneys & 0.169 & 0.173 & 0.0127 & \\
\hline Liver & 0.930 & 0.917 & 0.0818 & \\
\hline Lungs & 0.484 & 0.507 & 0.0321 & \\
\hline Blood & 1.55 & 1.75 & 0.130 & \\
\hline Stomach ${ }^{3}$ & 1.08 & 1.43 & 0.087 & 0.02 \\
\hline Smati intestine & 0.648 & 0.450 & 0.0445 & 0.01 \\
\hline Lange intestine plus cecum & 0.738 & 0.957 & 0.0769 & 0.08 \\
\hline
\end{tabular}

1 ingesta was removed from digestive tract

2 P-value listed if $\leq 0.10$

"includes the reticulum, rumen, omasum and abomasum

\section{Plasma metabolites}

Plasma urea $\mathrm{N}$ and total protein concentrations in Phase 1 changed quadratically $(P<0.01)$ as sampling day advanced, although the magnitude of difference among times were not great (Table 3). While plasma glucose concentration in Phase 1 varied with sampling time both quadratically $(\mathrm{P}<0.01)$ and cubically $(\mathrm{P}=0.09)$, values ranged only from 73 to $82 \mathrm{mg} / \mathrm{dl}$. In contrast to the change with time in Phase 1 urea concentration, in Phase 2 the concentration of urea decreased and then increased as age and sampling time increased (quadratic; $\mathrm{P}<0.01$ ). and glucose concentration changed similarly (quadratic; $\mathrm{P}<0.01$ ). The mean concentration of NEFA was greater in Phase 1 vs Phase $2(\mathrm{P}<0.01)$. The mean concentration of glucose was greater $(P<0.01)$ in Phase 2 , and the mean urea concentration was similar $(\mathrm{P}<0.10)$ between phases.

Orthogonal contrasts for effects of advancing time were significant for Phase 1 concentrations of seven of the 14 amino acids quantified (i.e., Ser, His, Tyr, Val, 
and Phe), with two being essential (Table 4). These effects were quadratic for four amino acids and cubic for three. Conversely, during Phase 2, concentrations of Ser, His, Gly, Thr, Ala, Arg, Tyr, Val, Met, Phe, Ile, Leu, and Lys increased linearly (PŁ0.01) with advancing sampling time, whereas Glu concentration decreased linearly $(\mathrm{P}<0.01)$.

TABLE 3

Plasma constituent concentrations for Boer x Alpine wethers at 31 (Phase 1) or $50 \mathrm{wk}$ of age (Phase 2)

\begin{tabular}{|c|c|c|c|c|}
\hline Phase & $\begin{array}{l}\text { Age } \\
\text { week }\end{array}$ & $\begin{array}{l}\text { Urea nitrogen } \\
\mathrm{mg} / \mathrm{di}\end{array}$ & $\begin{array}{c}\text { Glucose } \\
\mathrm{mg} / \mathrm{dl}\end{array}$ & $\begin{array}{l}\text { Nonesterified fatty } \\
\text { acids meq/l }\end{array}$ \\
\hline \multirow[t]{8}{*}{1} & 14 & 29.5 & 70.2 & 609 \\
\hline & 18 & 30.8 & 81.8 & 580 \\
\hline & 22 & 34.3 & 80.2 & 589 \\
\hline & 26 & 32.9 & 75.1 & 576 \\
\hline & 30 & 31.1 & 73.0 & 617 \\
\hline & $\mathrm{SE}$ & 1.18 & 2.85 & 19.8 \\
\hline & Effect' & Q & $\mathrm{Q}, \mathrm{c}$ & \\
\hline & Mean ${ }^{2}$ & 31.7 & 76.08 & $594^{\circ}$ \\
\hline \multirow[t]{8}{*}{2} & 38 & 27.7 & 93.8 & 136.5 \\
\hline & 42 & 33.4 & 111.6 & 145.4 \\
\hline & 46 & 31.7 & 102.0 & 125.1 \\
\hline & 50 & 29.7 & 88.3 & 100.9 \\
\hline & $\mathrm{SE}$ & 1.25 & 4.62 & 17.1 \\
\hline & Effect & Q & $\mathrm{Q}$ & \\
\hline & Mean' & 30.6 & $98.9^{\mathrm{b}}$ & $127^{\mathrm{b}}$ \\
\hline & Phase mean SE & 0.98 & 2.59 & 12.8 \\
\hline
\end{tabular}

effect: $\mathrm{Q}=$ quadratic effect of time $(\mathrm{P}<0.05) ; \mathrm{C}$ and $\mathrm{c}=$ cubic effect of time $(\mathrm{P}<0.05$ and 0.10 , respectively)

${ }^{2}$ average within phase

a.h phase means in a column without a common superscript letter differ $(\mathrm{P}<0.01)$

\section{DISCUSSION}

\section{Comparisons with other studies}

Body weight gain ( $228 \mathrm{~g} /$ day) in Phase 1 was greater than BW gain of $75 \mathrm{~g} /$ day noted by Morand-Fehr (1981) for Alpine goat kids at $30 \mathrm{wk}$ of age and consuming hay ad libitum as well as variable amounts (100 to $600 \mathrm{~g} /$ day) of concentrate, but was similar to $200 \mathrm{~g} /$ day $\mathrm{BW}$ gain by Boer goat kids under intensive management 
Plasma amino acid concentrations for Boer $x$ Alpine wethers at 31 (Phase 1) or 50 wk of age (Phase 2)

TABLE 4

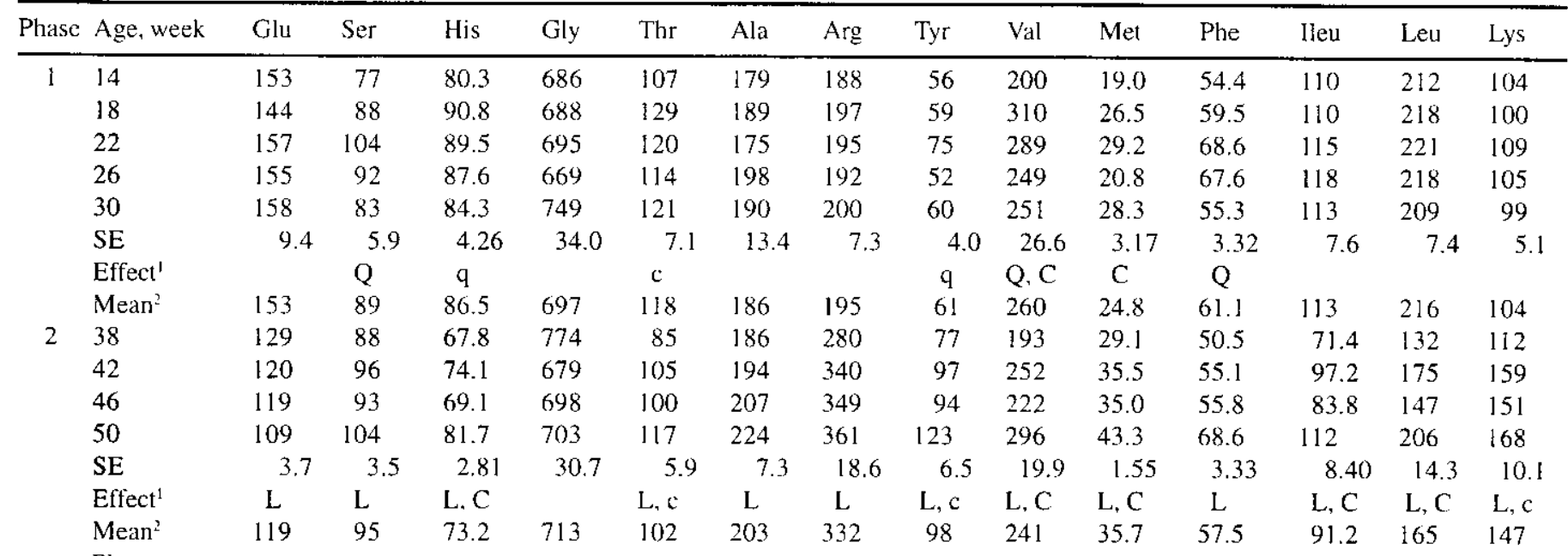

Phase

mean SE

$\begin{array}{llll}3.4 & 2.5 & 2.02 & 16.1\end{array}$

$3.6 \quad 5.8$

$\begin{array}{lllll}6.7 & 3.6 & 13.2 & 1.41 & 2.07\end{array}$

\begin{tabular}{lll}
4.30 & 6.5 & 4.4 \\
\hline
\end{tabular}

1 effect: $L$ and $l=$ linear effect of time $(P<0.05$ and 0.10 , respectively); $Q$ and $q=$ quadratic effect of time $(P<0.05$ and 0.10, respectively); $\mathrm{C}$ and $\mathrm{c}=$ cubic time $(\mathrm{P}<0.05$ and 0.10 , respectively $)$

${ }^{2}$ average within phase 
conditions, as reported by Van Niekerk and Casey (1988). The Phase 1 FCR of 0.19 was greater than the $0.11 \mathrm{FCR}$ for male castrate Bocr goat kids at approximately 7 months of age and consuming ad libitum a diet of $60 \%$ ground lucerne and $40 \%$ maize meal observed by Dreyer (1975). Likewise, BW gain and FCR for Boer $x$ Alpine crossbreds of the present experiment were generally superior to the results for other Boer crosses of similar age and with comparable management conditions, as summarized by Sahlu and Reis (1996).

Greater dressing percentage after Phase 2 than Phase 1 coincides with findings for goats of Van Niekerk and Casey (1988). The Phase 1 dressing percentage was similar to results of Potchoiba et al. (1990) with Alpines, of McCosker et al. (1998) with Boer x Saanen kids, and of Machen et al. (1996) with Boer x Spanish kids. Longissimus dorsi areas of 14.6 and $18.0 \mathrm{~cm}^{2}$ in Phases 1 and 2, respectively, were greater than noted by Machen et al. (1996) and Oman et al. (1996) with Boer x Spanish crossbred goats at 8 months of age and by Stanford et al. (1995) with Alpine kids at 3.5 months of age.

Approximately $3 \%$ of lamb carcasses is accounted for by $\mathrm{KPH}$ (Boggs and Merkel, 1993), which is lower than in the present experiment. Similarly, the percentage of KPH fat in the present experiment was greater than observed by Potchoiba ct al. (1990) for Alpine kids at $20 \mathrm{wk}$ of age, but less than reported by Colomer-Rocher et al. (1992) with New Zealand Saanen buck kids. The concentration of carcass fat in the present experiment was greater than noted by Machen et al. (1996) for 8-months-old Boer x Alpine crosses and by Dhanda et al. (1998) for 3-months-old Boer X Saanen crosses.

Even though no differences were noted between Phases in scores for carcass conformation, flank fat streaking, skeletal maturity, or lean maturity, the overall quality grade for Phase 2 was greater than for Phase 1, with the Phase 2 mean being between choice $e^{-}$and choice ${ }^{\circ}$ compared with between good $^{+}$and choice for Phase 1. Similar scores for Boer x Spanish goats were noted by Oman ct al. (1996). Lamb carcass grading standards were used in the present experiment, although there are differences between sheep and goats in sites of fat deposition. Cattle and sheep tend to deposit more subcutaneous and intermuscular fat than do goats, with cattle and sheep having only $25 \%$ of total fat in cavity and visceral depots compared with the $45 \%$ in goats (Potchoiba et al., 1990). This may relate to the unexpected difference between Phases in backfat thickness and the lack of significant correlation with other body fat measures. Thus, backfat thickness may not be a reliable indicator of fat levels in other parts of the body. Likewise, the Phase difference in carcass fat but not in noncarcass fat percentage, and a nonsignificant correlation between carcass and noncarcass fat percentages, indicate dissimilar change with age.

Hodgson (1971) reported that stomach growth in calves is related to age or BW as result of continuous ruminal mucosa and muscle growth, which can ex- 
plain greater stomach mass after Phase 2 than Phase 1. The marked difference between Phases in mass of the large intestine plus caecum may be at least partially attributable to the presence of more fat that could not be completely removed after Phase 2.

Plasma NEFA are bound to serum albumin and have a rapid flux, being replaced every 5 min (Hafez and Dyer, 1969). Plasma NEFA concentration can vary among sampling time more than fivefold within an animal in just a few hours, depending on nutritional status, energy demand, and stress. The release of NEFA from adipose tissue is under hormonal, neural, and nutritional controls (Hafez and Dyer, 1969). In this regard, factors responsible for the difference between Phases in NEFA concentration are unknown. The similar urea concentration between Phases suggests similar balance between levels of ruminally degradable protein and ruminally fermentable organic matter. Even though considerable glucose was required in both Phases, the higher level in Phase 2 could reflect slower BW gain and thus a lower glucose requirement. Linear increases with advancing time for many of the amino acids in Phase 2, but not in Phase, 1 , probably reflect a decreasing rate of protein synthesis with time in Phase 2 and less change in Phase 1 (Goetsch et al., 1998).

\section{Phase considerations}

Optimal slaughter weights for livestock production systems depend on many factors, among which are the pricing basis, consumer demands and desires, and production resources available. For example, if returns are based simply on the number of animals marketed rather than on BW or slaughter characteristics, then relatively low BW at slaughter is logical, such as at $31 \mathrm{wk}$. However, assuming that in most instances a heavy animal yields greater economic return than a light one, there are a number of advantages and disadvantages of producing a heavy animal to be considered and that are depicted by results of this experiment.

First, substantially lower BW gain and FCR in Phase 2 vs Phase 1 indicate a much greater feed cost per unit of BW gain. Another potential disadvantage to inclusion of Phase 2 is the increase in carcass fat concentration if very lean meat is preferred by consumers; however, there would be little effect if differences in fat level within this range do not markedly impact consumer appeal, as might be presumed. Even though BW gain was much lower in Phase 2 than in Phase 1, the limited increase in carcass fat concentration and no change in the level of noncarcass fat indicate continued protein deposition, albeit most likely at a slower and decreasing rate. In this regard, compared with sheep, goats appear to require more time to mature, typically have lower BW gain (Thonney et al., 1987) and, thus, may exhibit relatively greater lean tissue deposition in latter segments of lengthy feeding periods. Advantages or favourable attributes of the longer feeding period 
compared with Phase 1 alone, in addition to greater BW and carcass weight, are the greater dressing percentage, lower bone percentage of carcass, similar percentage lean in the carcass, and similar levels of KPH and noncarcass fat despite greater $\mathrm{BW}$, a tendency for greater longissimus dorsi area $(\mathrm{P}=0.11)$, and greater overall carcass quality grade. Conversely, factors that could be viewed as favourable for or promoting Phase 1 slaughter, in addition to greater BW gain and FCR, entail greater leg cut percentage and similar scores for carcass conformation, flank fat streaking, and lean maturity. Thus, in general it appears that BW gain and FCR were affected much more by prolonged feeding than were carcass characteristics other than weight and, thus, size of particular meat cuts. Therefore, feed costs and potential differences in product demand and price due to possible seasonal or holiday considerations would seem to be the major considerations when determining optimal time for slaughter of Boer $x$ Alpine wethers.

\section{CONCLUSIONS}

Boer x Alpine male castrates had appreciably greater BW gain and FCR in Phase 1 ( 14 to $31 \mathrm{wk}$ of age) than in Phase 2 ( 38 to $50 \mathrm{wk}$ of age). Most important carcass characteristics favourably affected by the lengthy feeding period were carcass weight and dressing percentage. In general, age did not have appreciable effects on other carcass characteristics, although the carcass fat percentage was 3.8 percentage units greater after Phase 2 than after Phase 1. Overall, it would appear that considerably more desirable marketing opportunities after Phase 2 than after Phase 1 would be required to justify the high feed costs of Phase 2 for Boer $x$ Alpine wethers.

\section{ACKNOWLEDGEMENTS}

The authors wish to acknowledge the laboratory technicians and farm crew of the E (Kika) de la Garza Institute for Goat Rescarch for sample analysis and animal care. Thanks are also expressed to R. C. Merkel for helpful review of the manuscript. 


\section{REFERENCES}

AOAC, 1990. Official Methods of Analysis. 15th Edition. Association of Official Analytical Chemists, Arlinglon

Aziz N.N., Murray D.M., Ball R.O., 1993. The effect of live weight gain and live weight loss on body composition of Merino wethers: Noncarcass organs. J. Anim. Sci. 71, 400-407

Blackburn H.D., 1995. Comparison of performance of Boer and Spanish goats in two US locations. J. Anim. Sci. 73, 302-309

Boggs D.L., Merkei R.A., 1990. Live Animal Carcass Evaluation and Selection Manual. 3rd Edition. Kendall/Hunt Publishing Co. Dubuque, 1A

Chaney A.L., Marbach E.P., 1962. Modified reagents for determination of urea and ammonia. Clin. Chem. 8, 130-136

Colomer Rocher F., Kirton A.H., Mercer G.J.K., Duganzich D.M., 1992. Carcass composition of New Zealand Saanen goats slaughtered at different weights. Small Ruminant Res. 7. 161-173

Dhanda J.S., Taylor D.G., Mclosker J.E., 1998. Growth, carcass and meat quality of buck kids reared to produce 'capretto' carcass. Anim. Prod. Aust. 22, 161-164

Dreyer C.J., 1975. Post weaning growth of Boer goats. Vleisnywerheid 33-35

Garza T., Garza L., 1997. Making money from Boer goat. Countryside Small Stock J. 81, 94-95

Glimp H.A., 1995. Meat goat production and marketing. J. Anim. Sci. 73, 29 1-29

Goering H.K., Van Soest P.J.,1970. Forage Fiber Analyses. Apparatus, Reagents, Procedures and Some Applications. ARS, USDA Agricultural Handbook, No. 379, pp. 1-12

Goetsch A.L., Galloway D.L., Patil A.R., 1998. Arterial amino acid concentrations in sheep consuming forage diets. Small Ruminant Res. 29. 51-60

Hafez E.S.E.. Dyer LA., 1969. Animal Growth and Nutrition. Lea and Febiger, Philadelphia, PA, pp. 121-137

Hodgson J.. 1971. The devclopment of solid feed intake in calves. 1. The effects of previous experience of solid food, and the physical form of the diet on the development of the alimentary tract. Anim. Prod. 13, 15-20

Machen R.V., Waldro D.F., Oman J.S., Griffin D.B., Savell J.W., 1996. Crossbreeding with the Boer to enhance growth and carcass quality. In: Proceedings of the Southeast Regional Meat Goat Production Symposium. Tallahassee, FL, pp. 87-90

McCosker J.E., Murray P.J., Mills A.W., Dhanda J.S., 1998. A comparison of six goat genotypes from birth to capretto live weight. Anim. Prod. Aust. 22, 411-418

Morand-Fehr R., 1981. Growth. In: C. Galt (Editor). Goat Production. Academic Press, London, pp. 253-283

Oma J.S., Grifim D., Ramsey W.S., Waldro D., 1996. Effects of brecd type on goat carcass composition, retail shelf live, sensory and chemical characteristics. In: Proceedings of the Southeast Regional Meat Goat Production Symposium. Tallahassee, FL, pp. 56-60

Owens F.N.. Gill D.R., Secris D.S., Coleman S.W., 1995. Review of some aspects of growth and development of fecdlot cattlc. J. Anim. Sci. 10,3152-3172

Potchoiba M.J., Lu C.D., Pinkerton F., Sahlu T., 1990. Effects of all milk diet on weight gain, organ development, carcass characteristics and tissue composition, including fatty acids and cholesterol contents, of growing malc goats. Small Ruminant Res. 3, 583-592

Puchala R., Pierzynowski S.G., Sahlu T.. 1998. Effect of methionine and hormones on amino acid concentration in the skin of Angora goats. Small Ruminant Res. 29, 93-102

Sahlu T., Reis P.J., 1996. Utilization of macro nutrients by meat goats. In: Procecdings of the Southeast Regional Meat Goat Production Symposium. Tallahassee, FL, pp. 8-13

SAS, 1990. SAS/STAT Uscr's Guide. Version 6.Vol. 2. 4th Edition. SAS Institute Inc. Cary, NC 
Stantord K., McAllister T.A., MacDougall M., Bailey D.R.C., 1995. Use of ultrasound for the prediction of carcass characteristics in Alpine goats. Small Ruminant Res. 15, 195-201

Thonney M.L., Taylor St C.S., McClelland T.H., 1987. Breed and sex differences in cqually mature sheep and goats. 1. Growth and food intake. Anim. Prod. 45. 239-26

USDA. 1982. Official United States Standards for Grades of Lamb. Yearling Mutton. and Mutton Carcasses. Agricultural Marketing Service, USDA. Washington, DC, pp. 1-17

Van Nickerk W.A., Cascy N.H., 1988. The Boer goat. II. Growth, nutrient requirements, carcass and meal quality. Small Ruminant Res. 1, 355-368

\section{STRESZCZENIE}

\section{Rozwój i charakterystyka tuszy koźląt Boer x Alpine, ubijanych w wieku 31 i 50 tygodni}

Masa ciała koźląt mięsnych zmienia się znacznie $z$ ich wiekiem, ale niewiele jest danych dotyczących różnic w przyrostach, wykorzystaniu paszy i charakterystyki tuszy kożląt ubijanych w różnym wieku.

W doświadczeniu przeprowadzonym na 14 kożlętach Boer x Alpine, o początkowej m.c. $14,0 \pm 0,6 \mathrm{~kg}$ oznaczano wpływ żywienia od 15-31 tygodnia (Okres 1) oraz od 38 do 50 tygoćnia życia (Okres 2) na pobranie i wykorzystanie paszy, przyrosty m.c., wybrane składniki plazmy krwi. masę narządów wewnętrznych oraz cechy tuszy. Zwierzęta żywiono do woli dawką zawierającą 20 lub $16 \%$ białka ogólnego oraz 33 lub 40\% NDF. odpowiednio w l i 2 okresie. Masa ciała na końcu okresów 1 i 2 wynosiła $42 \pm 2,0$ i $57 \pm 0,8 \mathrm{~kg}$, odpowiednio. Dzienne przyrosty m.c. były większe ( $\mathrm{P}<0.01$ ) w okresic 1 niż. 2 (228 vs $118 \mathrm{~g}$ ), równicż stosunek m.c. do ilości pobranej s.m. różnił się $(P<0.01)$ między okresami $(0,19-w 1$ vs $0,10-\mathrm{w} 2)$. Masa zimncj tuszy $(20,4$ vs $29,6 \mathrm{~kg} ; \mathrm{P}<0,01)$, wydajność rzeźna $(50,1$ vs $56,6 \% ; \mathrm{P}<0,01)$ oraz 7awartość tłuszczu w tuszy $(16,4$ vs $20,2 \% ; \mathrm{P}=0,09)$ były wiçksze na końcu okresu 2 niż 1 , natomiast udział udźca $(30,5$ vs $28,3 \% ; P=0,07)$ oraz kości w tuszy ( 23.7 vs $20,6 \% ; \mathrm{P}=0,01)$, a takżc grubość tłuszczu grzbietowego $(0,44$ vs $0,30 \mathrm{~cm} ; \mathrm{P}=0,04)$ byly większe po zakończeniu okresu 1 . Udział miçsa w tuszy $(58,3$ i $57,1 \%)$ i thuszczu wewnętrznego (nie tuszy) (6,39 vs 7.07\%, odpowiednio dla okresu 1 i 2 ) nie różnily się istotnie $(\mathrm{P}>0,10)$ między okresami.

W podsumowaniu autorzy podają, że zmiany w zawartości tłuszczu w tuszy i thuszczu wewnętrznego następujące wraz z wiekiem, oraz grubość thuszczu grzbictowcgo nic mogą być wiarygodnym wskaźnikiem różnic w składzie całego ciała, tuszy i ilości tłuszczu wewnętrzncgo. Średnic przyrosty dzienne i wykorzystanie paszy były znacząco gorsze u koźląt odchowanych do 50 niż 31 tygodnia życia, i muszą być porównywane ze zmianami w cechach tuszy celem określenia optymalnego terminu uboju. 